УДК 9

DOI $10.21661 / \mathrm{r}-553132$

Кучиев И.М., Сосранова 3.В.

\title{
СОВРЕМЕННАЯ МОЛОДЁЖЬ
}

\section{И ЕЁ РОЛЬ В ОБЩЕСТВЕННО-ПОЛИТИЧЕСКИХ ПРОЦЕССАХ}

Аннотация: во избежание каких-либо политических потрясений необходимо создание каналов, иными словами лифтов, благодаря которым медленными темпами произойдет транзит поколений в разных сферах общественной и политической жизни, молодёжь должна стать активным субъектом политических отномений, между государством и обществом.

Ключевые слова: молодёжная политика, отношения между государством и обществом, молодёжные субкультуры, ютюб, Тик Ток.

\section{Kuchiev I.M., Sosranova Z.V.}

\section{MODERN YOUTH AND ITS ROLE IN SOCIO-POLITICAL PROCESSES}

Abstract: in order to avoid any political upheavals, it is necessary to create channels, in other words, elevators, thanks to which the transit of generations in different spheres of public and political life will take place at a slow pace, young people should become an active subject of political relations between the state and society.

Keywords: YouTube, Youth policy, relations between the state and society, youth subcultures, Tik Tok.

Молодежь в большинстве не представляет единой политической и идеологической силы. Но именно она чаще всего является катализаторам политических изменений, здесь необходимо учитывать ее как возрастные, так и социально-психологические особенности, которые по разному ощущают и реагирует на исторические и политические процессы, в той или иной стране, чем старшее поколение, именно факт того что в России существует остро проблема «отцов и детей», связанная с тем что отцы, воспитывавшиеся в другой политической, идеологической и экономической среде, после распада СССР не смогли адаптироваться в 
новой экономической системе, из-за чего на фоне смены ценностей, идеологических постулатов возникают конфликты между поколениями; сложнее всего на Кавказе, где пока ещё существует коллективное мышление, проще в крупных городах, где происходит процесс урбанизации [5].

Поэтому в современном цивилизационном обществе нельзя, чтобы молодёжь была воспитана в однородной среде, где отсутствует конкуренция, свобода воли и творчества, нужно признать, что на данном этапе наше разношерстное общество живёт по жестким законам, тем самым лишая её современных базисов. Чаще всего молодёжь страдает в патриархальных и консервативных системах, где происходит нагнетание и непризнание новшеств.

Во избежание каких-либо политических потрясений необходимо создание каналов, иными словами лифтов, благодаря которым медленными темпами произойдет транзит поколений в разных сферах общественной и политической жизни. Молодёжь должна стать активным субъектом политических отношений, между государством и обществом.

Через вовлечение в общественно-политическую жизнь не только как участника какой-либо молодежной организации, но и как инициатора своего собственного проекта, то есть как Лидера.

Проблема политического просвещения особенно актуальна в условиях разных жизненных кризисных ситуаций, когда происходит социальная турбулентность, возникают вопросы психологического характера, понимание того, что мы не безучастный как к своей, так и общественно-политической жизни, происходит переосмысление старых позиций, так, например, после революции каждый молодой человек считал, что началась новая жизнь, и был заряжен энтузиазмом, ярким примером служат архитекторы-футуристы Я. Чернихов, Ф.О. Шехтел, Л.Н. Кекушева и т. д. Также поэты серебряного века: В. Маяковский, С. Есенин Н. Гумилёв, И. Северянин и др.

Сейчас в современной России возник ряд социально-экономических и политических проблем. 
Молодежь, в настоящее время испытывает трудности:

- в доступности качественного, современного образования;

- в отсутствии досуга для молодежи творческого студийного характера;

- в самореализации;

- в трудоустройстве;

- в открытии собственного бизнеса;

- в отсутствие доступного жилья;

- в недостаточности первичного капитала;

- с коррупцией в образовательных учреждениях.

Отсутствие перечисленного базиса, обостряет морально этическое воспитания как в семье, так и в обществе, а в условиях кризиса приводит к деградации общества и к его политической недееспособности. Государство перестаёт развиваться, так как отсутствует резерв кадров, способных заменять предшественников, а в молодёжной среде возникают субкультуры неправомерного характера, как правило, из среды гетто [10]. Одним из таких течений является секта АУЕ (переводится как «Арестантский уклад един»), туда в большинстве своём входят дети-подростки чаще всего из неблагополучных семей, это направление растёт в основном в недостаточно развитых городах или регионах. В качестве источника вдохновения послужила воровская романтика, сериалы криминального характера, вину возлагают также и на чиновников, не способных регулировать отношение между государством и обществом, неумение или нежелание выполнять качественные социальные программы.

В современном мире большую роль играет индивидуализм. Отношения в семье, социуме, в школе, к самому себе, понимание ответственности, самостоятельность, опыт жизни и стремление к воле - это совокупность качеств, которые делают человека индивидуальным и свободным. Благодаря окружающему миру, событиям политическим эта свобода реализуется не автоматически, механизмов ее реализации в образе жизни стало много - от гаджетов до социальных проектов.

Так, в современном мире появились новые субкультуры творческого характера, благодаря созданию разного рода медиаплатформ, первыми из них стали 
Тик-токеры (от английского слова Тик Ток это мессенджер), современная социальная сеть, в которую входят в основном подростки и молодые люди, ведущим направлением данной программы является развлекательный контент, делится контент на несколько типов-липсинк (lip sync). Подростки имитируют пение под музыку, танцуют или просто кривляются. Особую популярность получили вайны (короткие юмористические ролики, иными словами скетчи), челленджи (пользователи повторяют определенное действие) и дуэты (один пользователь в двойном окне приложения дополняет исходное видео своими действиями). Популярность данной программы связана с поиском молодых людей окна в мир искусства, славы и экономической независимости.

6 августа 2020 г. журнал Forbes выпустил свой первый рейтинг самых высокооплачиваемых звезд Тик Ток, согласно которому максимальный доход за 12 месяцев (с июня 2019 по июнь 2020 г.) составил 5 миллионов долларов США [11]. Критика данного мессенджера оправдана тем что, сама программа не несёт в себе просветительского, научно-популярного контента также может использоваться как против пользователя так и создателя по политическим причинам так в США программа не раз была уличена в краже и сборе дынных.

Пранкеры (от английского слова Prunc raffle) - видео- или телефонные хулиганы, главной целью их является розыгрыш человека, чтобы создать эмоционально психологическую обстановку, и снять на камеру происходящее. В отличие от Тик Тока в пранке бывает несколько направлений, развлекательные, научно-познавательные, спортивные и т. д. имеет несколько жанров:

- лайт - это вариант розыгрыша, при котором человек приходит в замешательство.

- хард - в этом случае жертва испытывает «психологическое давление» и выдает поток матерной брани, грозя расправой и наказанием через органы правопорядка;

- треш - это вариант хард-пранка, когда для достижения желаемого результата пранкер угрожает и оскорбляет человека. 
Технопранк - подразумевает в себе заранее тщательно подготовленный материал, в виде записей фраз (обычно хард - пранка). Известны случаи, когда жертва даже не подозревает, что спорит и ругается с записями своей собственной речи. Также есть пранки социального направления, часто проверка общества на любую острую социально-политическую тему, например, интерес на реакцию прохожих на имитирование противозаконных действий. Важно отметить юридическую оценку пранка. Согласно ст. 20.1 Кодекса об административных правонарушениях РФ, нецензурная брань в общественных местах и оскорбительное приставание к гражданам признаётся мелким хулиганством и влечёт наложение административного штрафа или ареста [12]. В юридической литературе к подобным действиям приравнивается и «телефонное хулиганство». Наказуемым является заведомо ложное сообщение о преступлении или происшествии, в частности, о террористическом акте. По мнению юристов, состава преступления, в том числе и по статье «мелкое хулиганство», в действиях звонящих нет, потому что пранки не нарушают общественный порядок.

Блогеры. Появления Ютюба стало историческим явлениям, так как телевизор был отправлен на второе место информационного поля, Всё больше людей стали основными потребителя видеохостинга. Ютюб славится огромным набором видео ресурсов, информационным полем разного жанра и направлений развлекательным, информационным, научно-популярным, образовательным, политическим, познавательным контентами. Людей, создающих эти контенты, называют блогерами, которые продают информацию, пишут статьи, согласно своему жанру и интересам аудитории. Ютюб - идеальная площадка конкурентно способных людей работающих в сфере медиа и информационных коммуникаций.

Если Тик Токер зарабатывает исключительно на количестве и качестве выпускаемых роликов, то блогер выполняет роль современного аудитора или журналиста, в зависимости от жанра, также он зависит от строгих регламентов и подписчиков: чем больше смотрят, тем больше заработок. Одним из известных Российских блогеров направления журналистика считается Юрий Дудь. С появлением иностранных программ и с активным их использованием меняется не 
только нравственно-ценностные качества, но и язык, речь идёт о сленге, который сейчас употребляется в молодёжной среде, в частности тик-токерами. Зачастую слова трансформируются из английского, китайского языков, но есть и примеры русского сленга, где слова или предложения просто сокращаются и искажаются: Дноклы-одноклассники, падра-подруга, хайп-шум, нуб-новичок, фаловеры-фанаты, бумер-представитель старшего поколения и т. д. В связи с этими быстро развивающими тенденциями, которые зачастую не принимаются людьми старше 50 лет, возникают сложности в сотрудничестве между двумя социальными группами.

В 20 в. в Европе и США обозначилась потребность в сознательном управлении творческой деятельностью человека, и, прежде всего, в политике, науке, технике и информационной среде: в условиях возрастающей конкуренции между индустриальными странами возникла необходимость в творческих кадрах, способных успешно решать проблемы геополитического характера, основной целью того или иного государства является лидерство [9].

Востребованность, конкурентоспособность молодого специалиста в сложившихся социально-экономических условиях во многом определяется не только его профессиональными знаниями, но и его личностными творческими способностями, главным смыслом которой становится единство личностной и общественной направленности.

В юношеском возрасте происходит осознание своего места в будущем, и от того, в какой среде и системе ценностей индивид развивается, в ходе которой осуществляет поиск самого себя и смысла жизни, будет зависеть не просто его трудовая деятельность, а скорее всего, познание ценностей общества и превращение их уже в индивидуальные ценности. В связи с этим для молодежи встают вопросы: в какой мере образ жизни в их власти и воле?

Высокие темпы развития цивилизации определяют потребность общества в творчески продуктивных личностях, способных к генерации и осуществлению новых идей и проектов. В связи с этим можно утверждать, что приоритетными направлениями деятельности руководителей высшего звена в любой сфере 
трудовой активности человека является выявление креативных личностей, поскольку идет соревнования мировых проектов, стимулированное мировым кризисом [6].

Молодое поколение должно быть готово к участию в этом состязании, и подготовку могут дать только научные знания. Молодежь, с одной стороны, это незащищенная группа, являющаяся, скорее, дестабилизирующей силой в обществе, а с другой, это поколение, от которого зависит будущее страны. Такой особый статус молодежи рождает потребность в адекватной молодежной политике, способной решить или смягчить имеющиеся проблемы, а также направить в созидательное русло творческий потенциал молодежи [7].

\section{Сиисок литературы}

1. Государственная молодёжная политика в законодательстве Российской Федерации: Сборник документов. чч. I-III / под общ. ред. В.А. Лукова. - М.: Социум, 2000.

2. Гудков Л.Д. Молодёжь России / Л.Д. Гудков, Б.В. Дубин, Н.А. Зоркая. М.: Московская школа политических исследований, 2011.

3. Гуляихин В.Н. Вхождение российской молодёжи в общественно-правовую жизнь: роль правовой социализации / В.Н. Гуляихин // Юридические исследования. - 2013. - №11. - С. 88-104.

4. Иваненков С.П. Проблемы социализации современной молодёжи / С.П. Иваненков. - СПб, 2003.

5. Ильин В.И. Быт и бытие молодёжи российского мегаполиса. Социальная структурация повседневности общества потребления / В.И. Ильин. - СПб.: Интерсоцис, 2007.

6. Молодёжь России и вызовы XXI века: социально-нравственные проблемы адаптации в новых исторических условиях / Под общ. ред. д-р экон. наук, профессора А.А. Шулуса. - М., 2001.

7. Чупров В.И. Молодёжь в общественном воспроизводстве, проблемы и перспективы / В.И. Чупров, Ю.А. Зубок. - М., 2000. 
8. Чупров В.И. Молодёжь в обществе риска / В.И. Чупров, Ю.А. Зубок, К. Уильямс. - М.: Наука, 2001.

9. Молодёжь России перед лицом глобальных вызовов на рубеже веков (как противостоять агрессивному экстремизму, ксенофобии и насилию среди молодёжи): материалы международной конференции, 18-19 ноября 2000г. - М.: Социум, 2001.

10. Материал из Википедии-свободной энциклопедии Гетто https://ru.wikipedia.org/wiki/Гетто

11. TikTok's 7 Highest-Earning Stars: New Forbes List Led By Teen Queens Addison Rae And Charli D’Amelio. // forbes.com. https://www.forbes.com/sites/abrambrown/2020/08/06/tiktoks-highest-earning-stars-teen-queens-addison-rae-and-charlidamelio-rule/?sh=17505f605087

12. «Кодекс Российской Федерации об административных правонарушениях» от 30.12.2001 N 195-Ф3 // КоАП РФ «Раздел II. Особенная часть» Глава 20. Административные правонарушения, посягающие на общественный порядок и общественную безопасность». Статья 20.1.// Мелкое хулиганство.

13. Мирман С.Д. Новые правила маркетинга и PR. Как использовать социальные сети, блоги, подкасты и вирусный маркетинг для непосредственного контакта с покупателем / С.Д. Мирман. - М.: Альпина Паблишер, 2011. - 352 с. ISBN 978-5-9614-1400-4.

\section{References}

1. Lukova, V. A. (2000). Gosudarstvennaia molodiozhnaia politika v zakonodatel'stve Rossiiskoi Federatsii: Sbornik dokumentov. chch. I-III. M.: Sotsium.

2. Gudkov, L. D., Dubin, B. V., \& Zorkaia, N. A. (2011). Molodiozh' Rossii. M.: Moskovskaia shkola politicheskikh issledovanii.

3. Guliaikhin, V. N. (2013). Vkhozhdenie rossiiskoi molodiozhi v obshchestvenno-pravovuiu zhizn': rol' pravovoi sotsializatsii. Iuridicheskie issledovaniia, $11,88-104$.

4. Ivanenkov, S. P. (2003). Problemy sotsializatsii sovremennoi molodiozhi. SPb. 
5. Il'in, V. I. (2007). Byt i bytie molodiozhi rossiiskogo megapolisa. Sotsial'naia strukturatsiia povsednevnosti obshchestva potrebleniia. SPb.: Intersotsis.

6. (2001). Molodiozh' Rossii i vyzovy XXI veka: sotsial'no-nravstvennye problemy adaptatsii v novykh istoricheskikh usloviiakh. M.

7. Chuprov, V. I., \& Zubok, Iu. A. (2000). Molodiozh' v obshchestvennom vosproizvodstve, problemy i perspektivy. M.

8. Chuprov, V. I., Zubok, Iu. A., \& Uil'iams, K. (2001). Molodiozh' v obshchestve riska. M.: Nauka.

9. (2001). Molodiozh' Rossii pered litsom global'nykh vyzovov na rubezhe vekov (kak protivostoiat' agressivnomu ekstremizmu, ksenofobii i nasiliiu sredi molodiozhi). M.: Sotsium.

10. Material iz Vikipedii-svobodnoi entsiklopedii Getto. Retrieved from https://ru.wikipedia.org/wiki/Getto

11. TikTok's 7 Highest-Earning Stars: New Forbes List Led By Teen Queens Addison Rae And Charli D'Amelio. https:. Retrieved from forbes.com.

12. "Kodeks Rossiiskoi Federatsii ob administrativnykh pravonarusheniiakh" ot 30.12.2001 N 195-FZ. KoAP RF "Razdel II. Osobennaia chast" Glava 20. Administrativnye pravonarusheniia, posiagaiushchie na obshchestvennyi poriadok $i$ obshchestvennuiu bezopasnost'". Stat'ia 20.1.

13. Mirman, S. D. (2011). Novye pravila marketinga i PR. Kak ispol'zovat' sotsial'nye seti, blogi, podkasty i virusnyi marketing dlia neposredstvennogo kontakta s pokupatelem., 352. M.: Al'pina Pablisher.

Кучиев Иосиф Мельсович - магистрант, ФГБОУ ВО «Северо-Осетинский государственный университет им. К.Л. Хетагурова», Владикавказ, Россия.

Kuchiev Iosif Melsovich - master's degree student, FSBEI of HPE "North Ossetia State University named after K.L. Hetagurov", Vladikavkaz, Russia.

Сосранова Залина Владимировна - доцент, канд. ист. наук, ФГБОУ ВО «Северо-Осетинский государственный университет им. К.Л. Хетагурова», Владикавказ, Россия. 
Sosranova Zalina Vladimirovna - associate professor, candidate of historical sciences, FSBEI of HPE "North Ossetia State University named after K.L. Hetagurov", Vladikavkaz, Russia. 